\title{
10
}

\section{Catching Values in Flight: A Process Perspective on Researching Values in Organisations}

\author{
Gry Espedal
}

\section{Introduction}

During the last few decades, the concept of process studies has become increasingly visible in social studies (Langley, Smallman, Tsoukas, \& de Ven, 2013; Langley \& Tsoukas, 2010, 2017), incorporating a new stream of how to study values work (Gehman, Trevino, \& Garud, 2013; Vaccaro \& Palazzo, 2015; Wright, Zammuto, \& Liesch, 2017), shedding light on how values work is shaping organisational forms, practices and activities. Values are part of the construction of the organisational life (Gehman et al., 2013), and we need approaches that help to identify and investigate the performative work of values in organisations, including temporal and relational aspects. In this chapter, I propose that studies of values work have not gone far enough in investigating how values institutionalise practices in organisations. Therefore, this chapter aims to investigate the question of how process studies can contribute towards

G. Espedal ( $\varangle)$

VID Specialized University, Oslo, Norway

e-mail: gry.espedal@vid.no 
identifying values work as strong-process studies, as how reality is brought into being in every instant, as well as weak-process studies-as interactions constituting institutionalising processes in organisations.

Throughout the decades, research on values has utilised a quantitative approach treating values as positivistic facts, measuring the degree of commitment to perceived values. For instance, the World Values Survey has carried out national surveys on values (Inglehart, 1977), and there have been studies on the effects on social cultures (Hofstede, 1980) and the motivational dimensions of values (Schwartz, 2006). Values have also been studied through using qualitative methods such as action research to investigate a reflective process for improving values work in organisations (Aadland \& Skjørshammer, 2012). Leaders are also shadowed to investigate their actions in relation to values (Askeland, 2016).

We can ask if these methodological approaches capture the mechanisms of values work in organisations, especially regarding how they are formed and informed by practices. Quantitative surveys identifying values investigate values as facts and not as intentional social objects or social practice. Action research pays more attention to the inquiry processes than to studying values work per se. Shadowing the practices of leaders in action does not capture the deeper temporal organisational engagement of values inhabited from the past and their influence on future standards of behaviour.

In organisations, there are many processes going on at the same time (Hernes, 2016). Actors operate within structures, technologies and legal systems. They are involved in history and in stories from the past, as well as processes which impose corporate strategies, visions and goals for the future (Hernes, 2014). These ongoing processes point inwards to occurrences within the organisations, but they are also based on responses and pressures from the outside. Process studies aim to unpack events in order to reveal an understanding of the complex activities and transactions that occur in organisations and contribute to their constitutions (Langley \& Tsoukas, 2010). As such, studying values as an organisational process can give insight to the underlying mechanisms, consciousness and broader awareness of value patterns in organisations.

Current studies of values work highlight values work in organisations as processes of ongoing performances situated in everyday practices 
(Gehman et al., 2013). Previous research on values is criticised for pursuing values work through cognitive and cultural lenses. Instead, the new stream of values work studies is enhancing values work performed and provoked in organisations as various types of processes articulating and accomplishing the desirables in relevance to right and wrong actions and behaviours (Espedal, 2019; Gehman et al., 2013).

Gehman et al.'s (2013) study proposes the concept that values work is comprised of key interrelated domains, such as concerns, networking and being part of value practices and discourses. Their study is followed by a few others, including a study on how change agents use values strategically to transform the highly resistant institutional setting of paying pizzo to the mafia at Sicily (Vaccaro \& Palazzo, 2015) and a study showing how the values of healthcare professionals are maintained in everyday work (Wright et al., 2017). One recent study identifies a process of value inquiry that is used to question the dominant value frames in situations of institutional pressure. Through a systematic analysis of three highly value-salient issues within a faith-based organisation, the study theorises the process of value inquiry as an open-ended process of questioning and reinterpreting the meaning of the dominant value frames. To adapt to this situation, institutions are inquiring the dominant value frame in order to seek out and find institutional values and practices to form new behaviours that realign with the common good and the values and agency of the organisations (Espedal, 2019).

In this chapter, I suggest that future developments in studying values work in organisations should include process perspectives. One may question if the recent stream of studies of values work in organisations has gone far enough in including the process nature of institutions and institutionalisation in their investigation of values (Surachaikulwattana \& Phillips, 2017). Therefore, in this chapter, I will cover how values work enhance actions and agency in influencing actors and institutions exemplified through a recent study of values work in a faith-based healthcare organisation. 


\section{Process Studies and Values Work}

Scholars have been engaging in a rather new field of process studies. Since the late 1990s, researchers have taken an explicitly agentic view of organisations and organising, researching routines, innovation, change, identity, strategising, decision-making, learning, knowing, communication and organised action (Langley \& Tsoukas, 2017). Several articles and books have described process thinking, process theorising and process research (Hernes, 2014, 2016; Langley, 1999, 2009; Langley \& Tsoukas, 2010, 2017). Since 2008, the interest in process studies has gathered researchers at Process Organization Studies (PROS) — a yearly conference focusing on studies in organisations that are grounded on process metaphysics-seeing processes, rather than substances, as the basic forms of the universe

Weick (1995)'s work on organising is highlighted as being revealing for process studies (Langley \& Tsoukas, 2017). The foundational notion of directing attention towards organising rather than organisation enables a new line of inquiry. This new emphasis invites scholars to examine how settings of interaction become organised, rather than hitherto research viewing organisations as already constituted entities. Organisation is highlighted 'to assemble ongoing interdependent actions into sensible sequences that generate sensible outcome' (Weick, 1979, p. 3). The researchers' task is to explain how organisations (the process) emerge. Key themes of process approach can include relationality, agency, constrained interactivity, emergence and open-endedness (Langley \& Tsoukas, 2017).

Process studies can be identified as strong- or weak-process studies (Bakken \& Hernes, 2006). Early studies of values and practices in organisations have studied values through a weak-process perspective. This perspective emphasises interactions as constituting processes. Weakprocesses assume that, for the most part, the task of process research is to provide arrows that connect pre-existing, relatively stable boxes in order to understand the temporal evolution of things or substances that nevertheless retain their identity over time. Through this perspective, organisations are viewed as relatively stable entities, time is primarily beheld chronologically and change is something that happens to the organisation (Langley \& Tsoukas, 2017). 
The examining of an introduction of core values and the investigation of how they influence activities and actions might be identified as a weak-process study. Often, core values' visibility is connected to being promoted in organisational strategies and mission statements. Core values are established among other activities, and the process might be identified as how values influence or change practices. Falkenberg (2006) has done a Norwegian study that investigates organisational core values through a weak-process perspective; this study investigates the characteristics of organisational core values.

Two other Norwegian studies can be characterised as being close to weak-process studies. Askeland (2014) includes institutionalising perspectives in understanding leaders' work and practices. This study argues that leaders may have a significant contribution to the institutionalisation process for the interpretation of the mission and the shaping of values in faith-based welfare organisations. However, the arrows that connect the pre-existing identity and mission point to relatively stable boxes that allow leaders to understand how they carry values that facilitate the temporal evolution of their organisations. Leaders are the subject, conveying value orientation through policy documents, and leaders build value orientation into the governing structures of their organisations. This study investigates leaders as actors and examines how they influence faith-based welfare organisations to maintain their value base, but it does not give insight to how values as a verb (valuing) constitute the conditions for this process (Bakken \& Hernes, 2006).

Aadland and Skjørshammer (2012) studied a faith-based healthcare organisation and the enhancement of humanistic and moral values through an action research process, identifying how the organisation is part of the societal processes of secularisation and pluralisation. The process identified in this study is closer to a strong value study that identifies values work and value discourses. The arrow in this study initiates a value process pointing to value discussions as generating ethical reflection and increasing the moral sensitivity (Eide \& Eide, 2008). The study describes how values work affects ethical work in the organisations, but we are not given insight into how values work per se influences this process.

In strong-process studies, change is not necessarily investigated as something that happens to things but as how reality is brought into being 
in every instant. The emphasis is on 'arrows all the way through' (Langley \& Tsoukas, 2017, p. 4), which means investigating how phenomena are constituted through the work that agents do. The study conducted by Gehman et al. (2013) is characterised as a strong-process study (Langley \& Tsoukas, 2017 , p. 4), which examines organisational values as a form of practice that is continually constituted and adapted through ongoing work enacted by organisational members.

Using process lenses, inspired by the practice theory of Schatzki (2002) and Dewey (1939), Gehman et al. (2013) conducted a tenyear study of the development of an honour code in a business school, where they looked for different processes in which the concept of values work was interrelated with organisational activities. Based on conveying archival sources, ethnographic observation and stakeholder interviews, Gehman et al. (2013) generated a new theory on understanding values as situated in practice. The process of values work was identified as emerging through dealing with pockets of concern, knotting local concerns into action networks and performing actual value practices that are circulated in value discourses.

Gehman et al.'s (2013) study has contributed to other studies of the effects that value practices provoke in organisations (Daskalaki, Fotaki, \& Sotiropoulou, 2018). Rather than a top-down procedure, it is through discussions, negotiations and ongoing community collaboration that value ideology is performed (VanderPal \& Ko, 2014). Despite the prevalence of the research, it is questionable whether Gehman et al.'s argument goes far enough in relation to investigating the work as part of the institutionalising processes. The study conducted by Gehman et al. (2013) implies a linear sequence where values (in the form of an honour code) first emerge in response to various concerns and are then practised. We can ask if the theory sufficiently emphasises the conditions of embedded agency and the role of institutional agents in relation to developing the institutions of value practices. From a strong-process theory, all values work, whether claims to core values by leaders or the enactment of professional values in everyday work (Wright et al., 2017), are constitutive acts (Ashcraft, Kuhn, \& Cooren, 2009) that serve a performative function in constructing people's understanding of organisational life. 
Vaccaro and Palazzo (2015, pp. 1094-1095) come closer to recognising values work as an institutionalising process, leaning on Schwartz's (1996, p. 2) definition of values as 'desirable, trans-situational goals'. As such, this study goes beyond the observation of emerging value practices by showing how change agents can use values strategically to transform a highly resistant institutional setting. This process involves viewing values as a motivational factor guiding principles in people's lives, challenging and changing highly resistant institutions through five micro-processes used to leverage values in interaction with stakeholders: hooking, anchoring, activating, securing and uniting.

\section{Process Studies' Role in Enhancing the Temporal and Relational Aspects of Organisational Work}

Time, timing and temporality are inherent in process studies, based on the notion that 'No motion is possible without the category of time' (Sorokin \& Merton, 1937, p. 615). The notion of time goes beyond the chronological conception of clock time (Ancona, Okhuysen, \& Perlow, 2001) and temporality can be enhanced in organisational processes by being viewed as an ongoing relationship between past, present and future (Schultz \& Hernes, 2013). Actors' ongoing present activities are continually enacted from past experiences by using presently available materials to enhance an organisation's future (Mead, 1932; Schultz \& Hernes, 2013). This temporal aspect presents a unique opportunity to study values as part of the situated agency, and how it is informed by the capacity to imagine alternative possibilities (Emirbayer \& Mische, 1998, p. 963).

Within various aspects of temporality, it is highlighted that 'process studies meet practice' (Langley et al., 2013, p. 5). Process studies draw upon the past and make it relevant to the present. This process is not viewed as a random exercise but as one that deepens the social practice in which actors are embedded. This can be seen, for instance, in the study conducted by Vaccaro and Palazzo (2015), the process of values 
work carried out by Addiopizzo is changing the practice of paying pizzo to the mafia by focusing on the processes of dignity and legality.

The relational aspect of organisational work is clearly processual. Experience is the deepest character of nature that bursts into existence in each moment (Mesle \& Dibben, 2017). We live in a complex world, and we need to understand what factors establish order and stability and how to achieve any degree of richness of experience. Investigating value processes can grant insight into relational power and the growth of values in our personal and communal experiences. Included in this are investigations into what is required to sustain relationships and supportively engage with others in an ongoing way. When studying the relational aspects of processes, values become an important mechanism for identifying who we are as people caring about various things in the world around us (Bednarek-Gilland, 2015). Whitehead (1957) highlights values as having an intrinsic nature, including a sense of immediate selfvaluing. Values nurture intentional openness in ourselves and others to the complexities and the contrasts in the world around us (Mesle \& Dibben, 2017).

We are never neutral towards the things we care about (BednarekGilland, 2015). We try, test and make subjective justifications, which again gives us ideas of what is good and how life might be lived. As such, values can be defined as things that matter to us trans-situatively-in specific situations as well as beyond the specificity of any situation-and trans-subjectively - not only for myself, but also for others (BednarekGilland, 2015, p. 19).

\section{Values as Part of Institutionalising Processes}

Part of old institutionalism and recent streams of institutional theory can be identified as process studies (Surachaikulwattana \& Phillips, 2017). While new institutionalism characterises institutions as stable and taken for granted (Meyer \& Rowan, 1977), the field has seen a shift from stability to institutional change and agency since the 1990s. The new trajectories of institutional work (Lawrence \& Suddaby, 2006) and institutional logic (Friedland \& Alford, 1991) have involved a growing focus 
on understanding and unravelling the processes and mechanisms of institutionalising by investigating how institutions are created, maintained and transformed as well as establishing a foundation for a social order (Surachaikulwattana \& Phillips, 2017).

Values as part of the organisational processes of institutionalism are highlighted by Suddaby, Elsbach, Greenwood, Meyer, and Zilber (2010). Leaning on Stinchcombe (1997, p. 8), Suddaby et al. argue that people accept institutions, not because these institutions have the right answers, but because they embody 'a value that people accept' (Suddaby et al., 2010 , p. 1235). For years, Selznick $(1957,2008)$ has highlighted values and ideals as part of the institutional processes of constructing the agency, actions and practices of organisations. This includes looking at organisational pressures and rivalries not as forms of mobilising individual egotism but as a natural social process in which the intention is to ask the right question on which ideals to treasure. Institutionalising then becomes a means of infusing the organisation with values beyond the technical requirements at hand in order to work on the institution as a natural product shaped by social needs and pressures (Selznick, 1957/1983, pp. 5, 17).

\section{Investigating Values Informed by Process Studies-A Strong-Process Perspective}

To understand values in leadership and organisations and their temporal and relational aspects, we need strong-process studies that investigate how values work is conditioned by organisational work and practices and how it is institutionalised. Since few have investigated the processes that enable the conditions for human agency and actions to maintain, change and disrupt institutions and values work from a strong-process study perspective, I will proceed by giving an example of such research in one faith-based organisation (Espedal, 2019). Many of the most obvious methodologies for conducting empirical research from a process perspective are not new in and of themselves. Historical analysis, ethnography and narrative approaches are well-established methods of natural analysis of evolving temporal phenomenon, but will be presented here, 
since they present ideas of process sensitivity. The case example represents a unique case (Yin, 2014) of being rich in the phenomenon of values work throughout 150 years of institutional history. Leaning on its history and conveying a triangulation of methods consisting of archival sources, ethnographic observation and semi-structured interviews, a fiveyear study on values work in this faith-based organisation was conducted.

Identifying the processes of values work in the organisation was implemented through studying processes from the outside and from within (Langley \& Tsoukas, 2017). Studying a phenomenon from the inside involves an effort to capture the evolving meaningful experience; in this case, looking at how meaning is taken care of by management and how the identities and callings of institutions are resurrected through values work. In the case of this organisation, the research was implemented through ethnographic work involving semi-structured interviews asking managers and employees at different levels open-ended questions about the organisation's activities, challenges and major concerns, as well as asking questions about how they saw values processes and value priorities at work.

To establish a process-sensitive approach, two approaches were conducted. First, catching the values in flight was implemented through asking questions starting with how, bringing in the temporal structures of the organisation's social practices and the uncertainty and urgency that were inherently involved in them (Langley et al., 2013). The driving assumption behind process thinking is that social reality is not steady state. It is a dynamic process. The overriding aim of the process analyst is therefore to catch the reality in flight, including values (Pettigrew, 1997). Open-ended questions regarding activities, challenges and the major concerns of the leaders and employees were asked, including question of how they knew that stories made a difference to people at work. Additionally, it was asked 'At work, what are the most important and difficult discussions you encounter?' and how the interviewees saw values processes and value priorities in their work.

Second, to identify the organisational aspects of reality in flight, sudden ruptures of change or the verb-influenced day-to-day practices that occurred in an unexpected, non-routine manner were observed and identified. A way to identify relevant changes and unexpected events can 
be shown through shadowing leaders (Czarniawska-Joerges, 2007) and looking for how events and actions were connected to ongoing value discourses. The aim was to investigate and observe values work in vivo in social situations. The observations were especially driven by an interest in investigating the performance of values work, but the observers were also engaged in questions about how values work is organised through talk and interaction.

A process-sensitive approach can also be to study a process from the outside, capturing the process through which a phenomenon developed over a chronology of time, with emphasis on how and why it happened or changed or on following changes of events set off by an incident or by accident (Van Hulst, Ybema, \& Yanow, 2017). In these studies of practices, a process researcher might move from treating these phenomena as stable entities to seeing them as entailing recurrent bricolages, breakdowns and improvisations. In the case organisation, it was when starting the analytical work on the data that the process of value inquiry emerged. A narrative approach (Rantakari \& Vaara, 2016; Riessman, 2008) was used to elicit the values work and value practices of the case organisation. Narratives play a key role in organisation process research due to their temporality, providing descriptions of sequences of events (Ricoeur, 1984). Narratives can offer knowledge of human intentions and deeds (Czarniawska, 2004, p. 650) and can play a crucial role in forming a landscape of action (Bruner, 1986). Accordingly, narratives can provide information on how things become organised (Boje, 1991) and on how members make sense of things (Boje, 2008).

Stories and episodes crucial to the organisation were added to a timeline, and tables were created for events, identifying their aims, actors, motivations and financial platforms. The historical timeline was bracketed into periods to compare and identify the different elements that facilitated the process of values work in the case organisation (Langley, 1999). In 1991, a chaotic situation was identified in the case organisation, as the hospital's existence was threatened by the municipality's suggestion to shut down the institution due to financial difficulties. This chaotic situation led to the establishment of a new strategic plan (2002) and a renewal of the organisational mission through launching two new core values: compassion and quality. The value of compassion pointed 
backwards to the practices of the case organisation over 150 years, and the value of quality was an answer to the demands and expectations of the healthcare authorities who funded the hospital. Therefore, values were studied retrospectively by looking back in time using archival sources such as annual reports and minutes from the board, as well as prospectively by observing the organisation and interviewing people at different times to deepen the investigation. Going through the data material, the author of the study searched for information-rich cases by using an intensity sampling approach (Patton, 2002, p. 234) that located value-salient issues. In zooming in on these stories, the author identified underlying assumptions for each issue and named them as elements of the process of value inquiry, including questioning the dominant value frame, reframing and reinterpreting and realigning values work.

The analytical work and theorising of the value inquiry process extend the emerging research on values work by highlighting the institutional work of organisation members and stakeholders as moving beyond a linear view of institutional complexity to maintain and change values and organisational agency in the face of plural demands. Unlike Gehman et al. (2013), this study does not reserve the term value practices for demarcated and recurrent bundles of actions that met specific timebound concerns, such as the performance of an honour code. Instead, this study found values work as include any set of acts in everyday work as being value-driven, and values work to be a particular set of actions that enhance the ongoing knowledge and reflection-creating processes that infuse an organisation with value-related actions (Espedal, 2019).

The process of value inquiry was identified as an open-ended process of questioning and reinterpreting the meaning of dominant value frames by continuously asking self-reflecting questions, such as 'What is our contribution now?' and 'Are we reaching those we are here for?' (Espedal et al., 2019). The process of value inquiry elaborates on the temporality and intertextuality of values work, suggesting conditions under which value inquiry becomes a dominant microprocess of building organisational meaning-making. The process of value inquiry occurs amidst a need to accommodate external demands and balance internal agency and 
practice. The process of self-reflection and the integration of values establish a central logic that guides and realigns organising principles and provides the organisation with a vocabulary of motive and sense of self.

The process of value inquiry is a response to a request from scholars of the institutional work tradition to investigate the relationship between actions and creation and between the maintenance and transformation of institutions (Lawrence \& Suddaby, 2006). It has been suggested that institutionalising processes affect institutions at a micro-level (Lawrence, Suddaby, \& Leca, 2009; Tolbert \& Zucker, 1996). These institutionalising processes infuse the organisation with values beyond the immediate technical requirements and work as a natural product in relation to social needs and pressures (Selznick, 1957/1983, pp. 5, 17). As such, this values work establishes a link between actions, agency and institutions.

\section{Concluding Remarks}

This chapter asks how process studies can contribute towards identifying values work and the institutionalising processes of values work in organisations. A new stream of values work studies is shedding light on how values work processes are shaping organisational forms, practices and activities. These process studies aim to unpack events to reveal an understanding of the complex activities and transactions of values work in organisations. However, one can ask if the recent stream of values work studies goes far enough in including the process nature of institutions and institutionalisation for instance through strong-process studies studying how reality is brought into being in every instant. In the illustrative study on a highly value-salient organisation, it is highlighted how process studies of values work can be conducted. The methodological approach being used conveys a triangulation of methods consisting of archival sources, ethnographic observation and semi-structured interviews. The described research project asked how activities, challenges and the major concerns of the leaders were enhanced through values work, bringing in temporal structures of social practice and looking for unexpected non-routines or sudden ruptures of change. The agentic capacity that the values were 
producing in the case organisation was used to identify how the organisation reorganised and reconstructed the habits and institutional agency through a process of value inquiry. The process of value inquiry established a profound process of institutionalisation meaning-making within the organisation.

As future studies, the processes of values work could be investigated in relation to several other topics. An interesting future process study could involve investigating the values work involved in for instance the worldwide \#MeToo campaign, either with an insider or an outsider perspective. The \#MeToo campaign started in October 2017 in the Hollywood film industry and has become a virtual revolution across the West. This campaign has swept over Europe, with uprisings in different countries, including within professional groups in Norway. Many have used the subject node and shared stories in virtual media. Under the keyword \#stilleføropptak (silent before shooting), the Norwegian newspaper Aftenposten published several stories together on 16 November 2017 with an appeal signed by almost 600 Norwegian actresses.

It would be interesting to investigate the \#MeToo campaign and the various associated mechanisms, issues and factors through examining how processes have maintained and changed the desirable modes of institutional values such as respect and disrespect. How are people's experiences with disrespect and violence establishing patterns of action? How are people re-establishing human worth through the campaign? How is this values work related to the development of moral work and ethical attitudes? Stories presented in testimonies complemented with news articles, blogs, columns, Facebook posts and letters to editors could be the objects of studies. The \#MeToo campaign has led to an increased awareness of managers' responsibility to prevent the problem and react in an active manner. In this regard, a question of investigation could involve identifying good practices and systems that establish people's safety when, for instance, making others aware of unwanted relationships at work. 


\section{References}

Aadland, E., \& Skjørshammer, M. (2012). From God to good? Faith-based institutions in the secular society. Journal of Management, Spirituality \& Religion, 9(1), 83-101.

Ancona, D. G., Okhuysen, G. A., \& Perlow, L. A. (2001). Taking time to integrate temporal research. Academy of Management Review, 26 (4), 512529.

Ashcraft, K. L., Kuhn, T. R., \& Cooren, F. (2009). Constitutional amendments: 'Materializing' organizational communication. The Academy of Management Annals, 3(1), 1-64.

Askeland, H. (2014). Leaders should be the carriers of institutional values: An account of how leaders contribute to the value-base of diaconal institutions. Diaconia: Journal for the Study of Christian Social Practice, 5(2), 147-175.

Askeland, H. (2016). Hverdagsledelse: Diakoni, Verdier og Ledelse i Praksis [Everyday leadership: Diaconia, values and leadership in practise] ( $\mathrm{PhD}$ thesis), The Faculty of Theology, Oslo, Norway.

Bakken, T., \& Hernes, T. (2006). Organizing is both a verb and a noun: Weick meets Whitehead. Organization Studies, 27(11), 1599-1616.

Bednarek-Gilland, A. (2015). Researching values with qualitative methods: Empathy, moral boundaries and the politics of research. London, UK: Ashgate Publishing Ltd.

Boje, D. M. (1991). The storytelling organization: A study of story performance in an office-supply firm. Administrative Science Quarterly, 36(1), $106-126$.

Boje, D. M. (2008). Storytelling organizations. Los Angeles, CA: Sage.

Bruner, J. S. (1986). Actual minds, possible worlds. Cambridge, MA: Harvard University Press.

Czarniawska, B. (2004). The uses of narrative in social research. In M. A. Hardy \& A. Bryman (Eds.), Handbook of data analysis (pp. 649-666). London: Sage.

Czarniawska-Joerges, B. (2007). Shadowing: And other techniques for doing fieldwork in modern societies. Malmø, Sweden: Liber/CBS Press.

Daskalaki, M., Fotaki, M., \& Sotiropoulou, I. (2018). Performing values practices and grassroots organizing: The case of solidarity economy initiatives in Greece. Organization Studies, 1-25.

Dewey, J. (1939). Theory of valuation (Vol. II). Chicago, IL: The University of Chicago Press. 
Eide, T., \& Eide, H. (2008). Verdien av en verdi-intervensjon. En studie av verdiarbeid $i$ et norsk sykehus [The value of a value-intervention. A study of value work in a Norwegian hospital]. Retrieved from Diakonhjemmet: https://vid.brage.unit.no/vid-xmlui/bitstream/handle/11250/98571/Eide\% 20og\%20Eide $\% 20-\% 20$ Verdien $\% 20$ av $\% 20$ en $\% 20$ verdi-intervensjon $\%$ 20Rapport $\% 202-2008$.pdf? sequence $=1$ \&isAllowed $=y$.

Emirbayer, M., \& Mische, A. (1998). What is agency? American Journal of Sociology, 103(4), 962-1023.

Espedal, G. (2019). Being compassionate. Institutionalizing through values work in a faith-based organization (PhD thesis). VID Specialized University, Oslo.

Espedal, G., Carlsen, A., \& Askeland, H. (2019). How do we reach out to those we are here for? Value inquiry in sustaining institutions. Work in process.

Falkenberg, G. (2006). Verdier og sosiale normer i store norske virksomheter. Viktige kulturbarere eller fordekt PR? Retrieved from http://www.fafo.no/ fafo/ media/com_netsukii/10028.pdf.

Friedland, R., \& Alford, R. R. (1991). Bringing society back in: Symbols, practices and institutional contradictions. In W. W. Powell \& P. J. DiMaggio (Eds.), The new institutionalism in organizational analysis (pp. 232-267). Chicago, IL: University of Chicago Press.

Gehman, J., Trevino, L. K., \& Garud, R. (2013). Values work: A process study of the emergence and performance of organizational values practices. Academy of Management Journal, 56(1), 84-112.

Hernes, T. (2014). A process theory of organization. Oxford, UK: Oxford University Press.

Hernes, T. (2016). Organisering $i$ en verden $i$ bevegelse [Organizing in a moving world]. Oslo, Norway: Cappelen Damm.

Hofstede, G. (1980). Culture's consequences: International differences in workrelated values. Beverly Hills, CA: Sage.

Inglehart, R. (1977). The silent revolution: Changing values and political styles among Western publics. Princeton, NJ: Princeton University Press.

Langley, A. (1999). Strategies for theorizing from process data. Academy of Management Review, 24(4), 691-710.

Langley, A. (2009). Studying processes in and around organizations. In D. Buchanan \& A. Bryman (Eds.), The Sage handbook of organizational research methods (pp. 409-429). Thousand Oaks, CA: Sage.

Langley, A., Smallman, C., Tsoukas, H., \& de Ven, A. V. (2013). Process studies of change in organization and management: Unveiling temporality, activity and flow. Academy of Management Journal, 56(1), 1-13. 
Langley, A., \& Tsoukas, H. (2010). Introducing perspectives on process organization studies. Process, Sensemaking and Organizing, 1(9), 1-27.

Langley, A., \& Tsoukas, H. (2017). Introduction: Process thinking, process theorizing and process researching. In A. Langley \& $\mathrm{H}$. Tsoukas (Eds.), The Sage handbook of process organization studies (pp. 1-25). Thousand Oaks, CA: Sage.

Lawrence, T. B., \& Suddaby, R. (2006). Institutions and institutional work. In S. R. Clegg, C. Hardy, T. B. Lawrence, \& W. R. Nord (Eds.), The Sage handbook of organization studies (2nd ed., pp. 215-254). London, UK: Sage.

Lawrence, T. B., Suddaby, R., \& Leca, B. (2009). Introduction: Theorizing and studying institutional work. In T. B. Lawrence, R. Suddaby, \& B. Leca (Eds.), Institutional work: Actors and agency in institutional studies of organizations (pp. 1-29). Cambridge, MA: Cambridge University Press.

Mead, G. H. (1932). The philosophy of the present. Chicago, IL: Open Court Publishing Company.

Mesle, C. R., \& Dibben, M. R. (2017). Whitehead's process relational philosophy. In A. Langley \& H. Tsoukas (Eds.), The Sage handbook of process organization studies. London, UK: Sage.

Meyer, J. W., \& Rowan, B. (1977). Institutionalized organizations: Formal structure as myth and ceremony. American Journal of Sociology, 83(2), 340363.

Patton, M. Q. (2002). Purposeful sampling. In M. Q. Patton (Ed.), Qualitative designs and data collection (pp. 230-245). Thousand Oaks, CA: Sage.

Pettigrew, A. M. (1997). What is a processual analysis? Scandinavian Journal of Management, 13(4), 337-348.

Rantakari, A., \& Vaara, E. (2016). Narratives and processuality. In A. Langley $\&$ H. Tsoukas (Eds.), The Sage handbook of process organization studies (pp. 271-286). London, UK: Sage.

Ricoeur, P. (1984). Time and narrative (Vol. I). Chicago, IL: University of Chicago Press.

Riessman, C. K. (2008). Narrative methods for the human sciences. Thousand Oaks, CA: Sage.

Schatzki, T. (2002). The site of the social: A philosophical exploration of the constitution of social life and change. University Park, PA: The Pennsylvania State University Press.

Schultz, M., \& Hernes, T. (2013). A temporal perspective on organizational identity. Organization Science, 24(1), 1-21.

Schwartz, S. H. (1996). Value priorities and behavior: Applying a theory of integrated value system. In C. Seligman, J. M. Olson, \& M. P. Zanna (Eds.), 
The psychology of values: The Ontario symposium (Vol. 8, pp. 119-144). Mahwah, NJ: Lawrence Erlbaum.

Schwartz, S. H. (2006). A theory of cultural value orientations: Explication and applications. Comparative Sociology, 5(2), 137-182.

Selznick, P. (1957/1983). Leadership in administration: A sociological interpretation. Berkeley, CA: University of California Press.

Selznick, P. (2008). A humanist science: Values and ideals in social inquiry. Stanford, CA: Stanford University Press.

Sorokin, P. A., \& Merton, R. K. (1937). Social time: A methodological and functional analysis. American Journal of Sociology, 42(5), 615-629.

Stinchcombe, A. L. (1997). On the virtues of the old institutionalism. Annual Review of Sociology, 23(1), 1-18.

Suddaby, R., Elsbach, K. D., Greenwood, R., Meyer, J. W., \& Zilber, T. B. (2010). Organizations and their institutional environments-Bringing meaning, values, and culture back in: Introduction to the special research forum. Academy of Management Journal, 53(6), 1234-1240.

Surachaikulwattana, P., \& Phillips, N. (2017). Institutions as process. In A. Langley \& H. Tsoukas (Eds.), The Sage handbook of process organization studies (pp. 372-387). London, UK: Sage.

Tolbert, P. S., \& Zucker, L. G. (1996). The institutionalization of institutional theory. In S. R. Clegg, C. Hardy, \& W. R. Nord (Eds.), Handbook of organization studies (pp. 175-190). London, UK: Sage.

Vaccaro, A., \& Palazzo, G. (2015). Values against violence: Institutional change in societies dominated by organized crime. Academy of Management Journal, 58(4), 1075-1101.

Van Hulst, M., Ybema, S., \& Yanow, D. (2017). Ethnography and organizational processes. In H. Tsoukas \& A. Langley (Eds.), The Sage handbook of process organization studies (pp. 223-236). London, UK: Sage.

VanderPal, G., \& Ko, V. (2014). An overview of global leadership: Ethics, values, cultural diversity and conflicts. Journal of Leadership, Accountability \& Ethics, 11(3), 166-175.

Weick, K. E. (1979). The social psychology of organizing (2nd ed.). Reading, MA: Addison-Wesley.

Weick, K. E. (1995). Sensemaking in organizations. Thousand Oaks, CA: Sage. Whitehead, A. N., \& Sherburne, D. W. (1957). Process and reality. New York, NY: Macmillan.

Wright, A. L., Zammuto, R. F., \& Liesch, P. W. (2017). Maintaining the values of a profession: Institutional work and moral emotions in the emergency department. Academy of Management Journal, 60(1), 200-237. 
Yin, R. K. (2014). Case study research: Design and methods (5th ed.). Thousand Oaks, CA: Sage.

Open Access This chapter is licensed under the terms of the Creative Commons Attribution 4.0 International License (http://creativecommons.org/ licenses/by/4.0/), which permits use, sharing, adaptation, distribution and reproduction in any medium or format, as long as you give appropriate credit to the original author(s) and the source, provide a link to the Creative Commons license and indicate if changes were made.

The images or other third party material in this chapter are included in the chapter's Creative Commons license, unless indicated otherwise in a credit line to the material. If material is not included in the chapter's Creative Commons license and your intended use is not permitted by statutory regulation or exceeds the permitted use, you will need to obtain permission directly from the copyright holder.

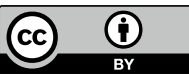

